\title{
The influence of land use systems on soil and surface litter fauna in the western region of Santa Catarina ${ }^{1}$
}

\author{
A influência do sistema de manejo do solo sobre a fauna edáfica e epígea na região \\ oeste catarinense
}

\author{
Marie Luise Carolina Bartz ${ }^{2 *}$, George Gardner Brown ${ }^{3}$, Renato Orso ${ }^{4}$, Álvaro Luiz Mafra e Dilmar Baretta
}

\begin{abstract}
The aim of this study was to evaluate the abundance of soil and surface litter fauna in the western region of Santa Catarina state, southern Brazil, in the following land use systems (LUS): no-tillage crops (NT), integrated crop-livestock (ICL), pasture (PA), Eucalyptus plantation (EP) and native forest fragments (NF). Sampling was done in three counties in the western region of Santa Catarina: Xanxerê, Chapecó and São Miguel do Oeste, in two seasons (winter and summer). The evaluation of soil/litter fauna in each LUS was performed by installing nine "pitfall traps" per sampling grid $(3 \times 3)$. The counties are true replicas. The soil for the chemical attributes was collected at the same sampling points for soil fauna. Altogether, 17 taxa were identified in the five LUS. The presence of groups of fauna was influenced by the type of soil management used. The LUS NF and EP provide better soil conditions for the development of a higher diversity of soil fauna groups compared to other LUS, which showed varying degrees of human intervention, regardless of the sampling season (winter or summer). However, annual crop systems NT and ICL groups showed greater richness and total abundance when compared to the perennial systems (EP and PA). Principal component analysis is an important tool in the study of biological indicators of sustainability because it allows use of soil attributes (chemical and physical) as explanatory environmental variables, which helps in the interpretation of ecological data.
\end{abstract}

Key words: Soil management systems. Soil biology. Soil biodiversity. Sustainability. Pitfall traps.

RESUMO - O objetivo deste estudo foi avaliar a abundância da fauna do solo e da serrapilheira na região oeste do estado de Santa Catarina, Brasil, nos seguintes sistemas de uso do solo (SUS): culturas sob plantio direto (NT), integração lavoura-pecuária (ILP), pastagem (PA), reflorestamento de eucalipto (EP) e fragmentos de floresta nativa (NF). As amostragens foram realizadas em três municípios da região oeste de Santa Catarina: Xanxerê, Chapecó e São Miguel do Oeste, em duas estações (inverno e verão). A avaliação da fauna do solo e da liteira em cada SUS foi realizada instalando-se nove armadilhas do tipo "Ptifall traps" em um grid amostral $(3 \times 3)$. Os municípios são as réplicas verdadeiras. O solo para a análise química foi coletado nos mesmos pontos da fauna. No total, foram identificados 17 táxons nos cinco SUS. A presença de grupos da fauna do solo foi influenciada pelo manejo de solo utilizado. Os SUS NF e EP apresentaram as melhores condições para o desenvolvimento de uma maior diversidade de grupos da fauna edáfica, comparados aos outros sistemas de uso do solo, que mostraram diferentes graus de intervenção humana, independentemente da época de amostragem (inverno ou verão). No entanto, os sistemas de cultivo anual NT e ILP apresentaram maior riqueza de grupos e abundância total, comparados aos sistemas perenes (EP e PA). A análise de componentes principais é uma importante ferramenta nos estudos de indicadores de sustentabilidade, pois ajudam na interpretação dos dados ecológicos.

Palavras-chave: Sistemas de uso do solo. Biologia do solo. Biodiversidade do solo. Sustentabilidade. Armadilhas Pitfall.

\footnotetext{
*Autor para correspondência

${ }^{1}$ Recebido para publicação em 20/01/2014; aprovado em 20/06/2014

Pesquisa financiada pela FAPESC projeto $n^{\circ} 6.309 / 2011-6$ e CNPq pelo projeto $n^{\circ} 563251 / 2010-7$

${ }^{2}$ Programa de Pós-Graduação em Gestão Ambiental, Universidade Positivo em Curitiba, Rua, Prof. Pedro Viriato Parigot de Souza, 5300, Cidade Industrial, Curitiba-PR, Brasil, 81.280-330, bartzmarie @up.edu.br

${ }^{3}$ Embrapa Florestas, Colombo-PR, Brasil, george.brown@embrapa.br

${ }^{4}$ Departamento de Zootecnia, Centro de Educação Superior do Oeste, Universidade do Estado de Santa Catarina, Chapecó-SC, Brasil, renato_ orso@hotmail.com,dilmar.baretta@udesc.br

${ }^{5}$ Centro de Ciências Agroveterinárias, Universidade do Estado de Santa Catarina, Chapecó-SC, Brasil, a2alm@cav.udesc.br
} 


\section{INTRODUCTION}

The intensification of land use and severe anthropic interventions, whether for human occupancy or agricultural production, lead to changes in soil quality. Soil quality is defined as the ability of soil to function within the ecosystem and the limit of soil use and that allows biological sustainability as well as contributes to the maintenance and growth of plants, animals and man (BARETTA et al., 2011; BONEA et al., 2010).

The organisms found in soil and surface litter, especially the representatives of meso and macrofauna, have a determining role in soil processes, such as: nutrient cycling, organic matter decomposition and improvement of such physical attributes as aggregation, porosity and water infiltration(BARETTA et al., 2011; HUERTA; WAL, 2012). Therefore physical, chemical and microbiological attributes can be used as explanatory environmental variables to understand the functioning of the soil, and to assess their influence on the diversity of edaphic invertebrates such as springtails and other groups (BARETTA et al., 2008a; VASCONCELLOS et al., 2013).

Currently much has been discussed regarding differences between soil management systems and their impact on soil quality. No-tillage (NT) is a system that has been widely used in the state of Santa Catarina. Among the main features of no-tillage is that minimal soil preparation, a constant soil cover and crop rotation creat more favorable conditions for the development of soil organisms, that are practically absent in monocropped-conventional tillage, resulting in higher soil degradation, increased compaction and the lack of food, especially the absence of cover necessary for the survival of the soil organisms (ALVES; BARETTA; CARDOSO, 2006; BARTZ et al., 2013; BROWN et al., 2003).

Environmental quality indicators (biological, physical and chemical) are important in identifying changes in ecosystems, enabling evaluation of the variables more sensitive to these processes (LIMA et al., 2013). According to Araujo and Monteiro (2007) an effective soil indicator must be part of the chemical, physical or biological properties that are interfering in ecological processes and thus can be easily applied.

Knoepp et al. (2000) report that many functions and properties of soil fauna can be used as quality indicators. For example, the presence of specific individuals or populations or biological processes that affect soil structure.

Due to the lack of research on soil quality indicators in southern Brazil, especially in Santa Catarina state, this study was conducted in order to verify the potential of soil and surface litter fauna as a bioindicator in management systems and also to verify the relationship of the major groups with other soil attributes.

\section{MATERIAL AND METHODS}

The study was carried out in the western region of Santa Catarina (SC) state, Brazil. Study sites were randomly selected in the region, and includes three counties: São Miguel do Oeste, Chapecó and Xanxerê (BARTZ et al., 2014). Each county was considered a true replicate and five different LUS were selected per county, representing a gradient of increasing land-use intensity: annual cropping under no-tillage (NT), integrated croplivestock with no-tillage (ICL), pastures (PA), Eucalyptus plantations (EP) and native forest fragments (NF).

Selected characteristics of each sample site are presented in Table 1. The sites ranged from 593-746 m elevation. The climate in the region is subtropical humid with warm summers (Cfa) (Koeppen classification), with mean temperatures $18-22{ }^{\circ} \mathrm{C}$. The region has no marked dry season and rain falls throughout the year. Soils at the sites were classified generally as clayey Typic Hapludox (SOIL SURVEY STAFF, 2010).

The NF fragments were generally small (1-10.8 ha) and consisted of a transition from mixed Araucaria forest to semi-deciduous seasonal secondary forest, where some of the forest trees lose their leaves in the winter season. In several of the forests either people or cattle regularly entered, and paths were frequently observed. The EP ranged from 1-6 ha in size, and 4-21 yr of age and in several locations had previously been native grassland. The PA ranged from 2.6-6 ha in size and 4-15 yr in age, and were native, introduced or mixedgrass pastures. The NT systems involved minimum soil disturbance, permanent soil cover and crop rotation. NT fields ranged from 2.2-6.2 ha in size and 4-18 yr since adoption of no-tillage. The ICL fields ranged from 1.85.1 ha in size and 8-18 yr of age. ICL is an agricultural management system with annual cropping (planted using NT) in summer and with cover crops (oat, wheat, grass) in winter so it can be that are used for livestock grazing. Both ICL and NT are considered more intensified systems due to cropping and frequent use of external inputs such as herbicides, fungicides and insecticides. Due to the lack of information on local soil fauna assemblages, we reduced the sampling areas to approximately one hectare (1 ha plot) in order to avoid confounding factors that may influence soil organisms distribution within each system, such as slope, different solar exposure and variation in soil characteristics.

At each site, soil/litter fauna were sampled using the Pitfall traps place at nine points distributed every $30 \mathrm{~m}$ on a regular grid $(3 \times 3)$ that was 20 meters 
Table 1 - Selected environmental and management characteristics of the sampling sites and LUS (NF: native forest, EP: Eucalyptus plantation, PA: pasture, ICL: integrated crop-livestock and NT: no-tillage) in each county of the western region of Santa Catarina

\begin{tabular}{|c|c|c|c|c|c|}
\hline LUS & Altitude m & UTM J22 zone & Size ha & Age yr & Vegetation \& Management \\
\hline \multicolumn{6}{|r|}{ XANXERÊ } \\
\hline $\mathrm{NF}$ & 714 & $\begin{array}{l}355588,1298 \\
7031160,621\end{array}$ & 1 & - & $\begin{array}{l}\text { Transition between mixed ombrophylous forest and semi-deciduous } \\
\text { seasonal forest. Secondary forest. }\end{array}$ \\
\hline $\mathrm{EP}$ & 709 & $\begin{array}{l}354841,1068 \\
7036628,879\end{array}$ & 6 & 4 & Native grassland previously. \\
\hline PA & 723 & $\begin{array}{l}353941,0463 \\
355588,1298\end{array}$ & 4.2 & 12 & Introduced pasture (Axonopus affinis). Manure input. \\
\hline ICL & 714 & $\begin{array}{l}7031160,621 \\
354841,1068\end{array}$ & 1.9 & 8 & $\begin{array}{l}\text { Minimum tillage with crop rotation (soybean - Glycine max, maize } \\
\text { Zea mays, black oats - Avena strigosa, annual ryegrass - Lolium } \\
\text { multiflorum). Use of herbicides, insecticides and fungicides. }\end{array}$ \\
\hline NT & 746 & $\begin{array}{r}7036628,879 \\
7030597,288\end{array}$ & 6.2 & 18 & $\begin{array}{l}\text { No-tillage (soybean, maize, wheat - Triticum aestivum). Use of } \\
\text { herbicides, insecticides and fungicides. }\end{array}$ \\
\hline \multicolumn{6}{|c|}{ SÃO MIGUEL DO OESTE } \\
\hline NF & 648 & $\begin{array}{l}247891,0742 \\
7040008,463\end{array}$ & 10.8 & $>50$ & $\begin{array}{l}\text { Transition between mixed ombrophylous forest and semi-deciduous } \\
\text { seasonal forest. Secondary forest. Occasional presence of people. }\end{array}$ \\
\hline EP & 659 & $\begin{array}{l}247846,9837 \\
7040639,510\end{array}$ & 2.6 & 7 & Native grassland previously. \\
\hline PA & 660 & $\begin{array}{l}247970,7384 \\
247891,0742\end{array}$ & 1.9 & 50 & $\begin{array}{l}\text { Introduced pasture mixed with native grasses. Accidentally burned } \\
\text { in } 2007 .\end{array}$ \\
\hline ICL & 641 & $\begin{array}{l}7040008,463 \\
247846,9837\end{array}$ & 1.8 & 18 & $\begin{array}{l}\text { No-tillage with crop rotation (soybean, maize, black oat, annual } \\
\text { ryegrass). Use of herbicides, insecticides and fungicides. }\end{array}$ \\
\hline NT & 642 & $\begin{array}{l}7040639,510 \\
7039329,886\end{array}$ & 3.2 & 4 & $\begin{array}{l}\text { No-tillage with crop rotation (soybean, maize, black oats, annual } \\
\text { ryegrass). Use of herbicides. Last two yr. without insecticides. }\end{array}$ \\
\hline & & & & & CHAPECÓ \\
\hline $\mathrm{NF}$ & 623 & $\begin{array}{l}331686,9798 \\
7008603,136\end{array}$ & 7.6 & $>50$ & $\begin{array}{l}\text { Transition between mixed ombrophylous forest and semi-deciduous } \\
\text { seasonal forest. Secondary forest. Entrance of people. }\end{array}$ \\
\hline $\mathrm{EP}$ & 653 & $\begin{array}{l}332063,2933 \\
7009274,894\end{array}$ & 3.5 & 15 & $\begin{array}{l}\text { Accidentally burned in } 2006 \text {. Manure input. Accidentally burned } \\
\text { in } 2006 \text {. }\end{array}$ \\
\hline PA & 642 & $\begin{array}{l}336900,3742 \\
331686,9798\end{array}$ & 5.4 & 50 & Native grass. \\
\hline ICL & 593 & $\begin{array}{l}7008603,136 \\
332063,2933\end{array}$ & 5.1 & 10 & $\begin{array}{l}\text { No-tillage with crop rotation (soybean, maize, black oats, annual } \\
\text { ryegrass). Use of herbicides, insecticides and fungicides. }\end{array}$ \\
\hline NT & 679 & $\begin{array}{r}7009274,894 \\
7010937,325\end{array}$ & 2.2 & 10 & $\begin{array}{l}\text { No-tillage (soybean, maize, wheat). Use of herbicides, insecticides and } \\
\text { fungicides. }\end{array}$ \\
\hline
\end{tabular}


from the plot border (BARTZ et al., 2014). Sampling was carried out during the winter (August, 2011) and summer (December, 2011). The soil fauna were fixed/ preserved in $92.8 \%$ ethanol, counted and identified at order or taxonomic groups.

To determine environmental characteristics (chemical and physical soil attributes) 15 subsamples were taken around each trap, to a depth of 0 to $20 \mathrm{~cm}$ and bulked. The samples were homogenized and sieved at $2 \mathrm{~mm}$ mesh. The bulked sample was taken for analysis of the following chemical attributes: $\mathrm{pH}$ in water (hydrogen potential in water), $\mathrm{pH}$ in SMP buffer, $\mathrm{P}$ (phosphorous available by Mehlich-1 solution), K (exchangeable potassium), Al (exchangeable aluminum), Ca (exchangeable calcium), Mg (exchangeable magnesium), OM (organic matter by Walkley-Black method), $\mathrm{H}+\mathrm{Al}$ (potential acidity), CEC (cation exchange capacity) and sum of bases, according to the method described in Tedesco et al. (1995). Also the clay contents were measured (TEDESCO et al., 1995) as a physical attribute.

Data were plotted for relative frequency in each LUS and season. The less abundant groups: Hemiptera, Isoptera, Orthoptera, Blattodea, Chilopoda, Dermaptera, Diplopoda, Homoptera, Thysanoptera and unidentified organisms were combined to create a group called "others". Total taxa richness was estimated and Shannon and Pielou indices were calculated using standard formulas (ODUM, 1983).

Total abundance per LUS was submitted to an ANOVA, followed by Fischer's Protected LSD test at $P<0.05$ confidence level (STATSOFT INC., 2001). The organisms' abundance in each taxa of soil fauna in the LUS was used to obtain the length of gradient in a Detrended Correspondence Analysis (DCA) and, as this was less than three (linear response), we opted for the Principal Component Analysis (PCA) using the program CANOCO version 4.0 (TER BRAAK; SMILAUER, 1998). Significant environmental attributes $(P<0.05)$ selected using Monte Carlos permutations, were subsequently used in the PCA as explanatory variables for changes in groups of soil/litter fauna.

\section{RESULTS AND DISCUSSION}

In the five land use systems (LUS) assessed, a total of 17 taxonomic groups of the soil/litter fauna [Collembola, Acarina, Araneae, Coleoptera, Grylloblattodea, Formicidae, Hymenoptera, Isopoda, Hemiptera, Isoptera, Orthoptera, Blattodea, Chilopoda,
Dermaptera, Diplopoda, Homoptera and Thysanoptera], and also Others (unidentified organisms) were found.

There were changes in total abundance, richness of groups and in the distribution of the relative frequency of groups of fauna among the LUS during the two seasons sampled (winter and summer) (Figures 1 and 2 and Table 2). Similar results were also found by several authors who have studied the influence of soil management on the abundance of soil fauna in the state of Santa Catarina (ALVES; BARETTA; CARDOSO, 2006; BARETTA et al., 2006).

Figure 1 - Relative frequency of the main soil/litter organisms captured in different land use systems using Pitfall traps, in the winter season (August 2011) of the western region of Santa Catarina, Brazil. (NT: no-tillage, ICL: integrated croplivestock, PA: pasture, EP: Eucalyptus plantation and NF: native forest)

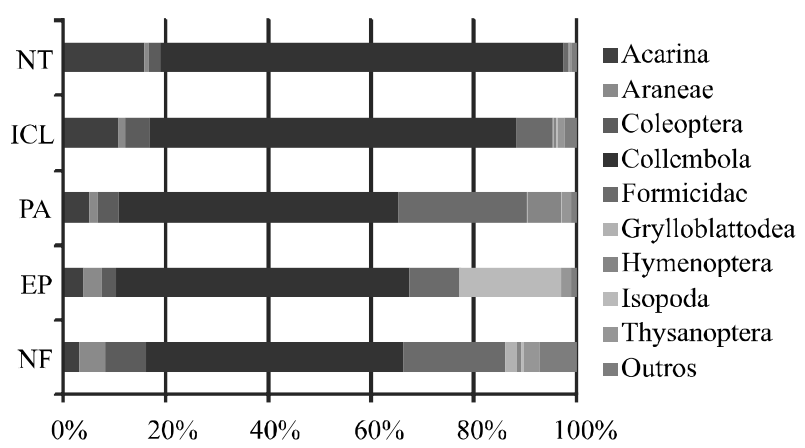

Figure 2 - Relative frequency of the main soil/litter organisms captured in different land use systems using Pitfall traps, in the summer season (December 2011) of the western region of Santa Catarina, Brazil. (NT: no-tillage, ICL: integrated crop-livestock, PA: pasture, EP: Eucalyptus plantation and NF: native forest)

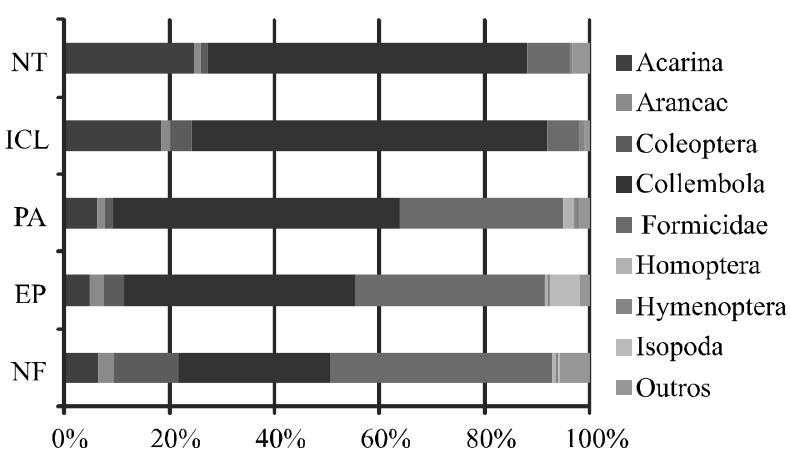


Table 2 - Soil/litter fauna parameters in native forest (NF), Eucalyptus plantation (EP), pasture (PA), integrated crop-livestock (ICL) and no-tillage (NT) using Pitfall traps in winter (Win) and summer (Sum) seasons in the western region of Santa Catarina state,

\begin{tabular}{lcccccccc}
\hline \multirow{2}{*}{ LUS } & \multicolumn{2}{c}{ Total abundance (individuals) } & \multicolumn{2}{c}{ Total taxa richness per LUS } & \multicolumn{2}{c}{ Shannon index $\left(\mathrm{H}^{\prime}\right)$} & \multicolumn{3}{c}{ Pielou index $(\mathrm{J})$} \\
\cline { 2 - 9 } & Win* & Sum* & Win & Sum & Win & Sum & Win & Sum \\
\hline NF & $1286 \mathrm{aA}$ & $2206 \mathrm{aB}$ & 17 & 17 & 0.73 & 0.68 & 0.59 & 0.55 \\
EP & $1372 \mathrm{a}$ & $1769 \mathrm{a}$ & 13 & 15 & 0.59 & 0.61 & 0.53 & 0.52 \\
PA & $3139 \mathrm{~b}$ & $3120 \mathrm{a}$ & 13 & 16 & 0.59 & 0.53 & 0.53 & 0.47 \\
ICL & $3051 \mathrm{~b}$ & $3228 \mathrm{a}$ & 15 & 14 & 0.47 & 0.46 & 0.40 & 0.40 \\
NT & $3041 \mathrm{bA}$ & $3915 \mathrm{bB}$ & 16 & 14 & 0.33 & 0.49 & 0.27 & 0.49 \\
\hline
\end{tabular}

*Numbers followed by different lower case letters mean significant $(P<0.05)$ differences between LUS (NF, EP, PA, ICL and NT), while different upper case letters mean significant differences between the seasons (winter and summer ) in a particular LUS according to Fischer's Protected LSD test

The relative frequency of the groups in the winter season was influenced by the LUS and the groups most frequently found in all LUS were: Collembola, Acarina, Coleoptera and Formicidae (Figure 1). The groups Collembola and Acarina were more frequently found in the farmlands and less frequently in PA, EP and NF, respectively. The opposite was observed for Formicidae.

The relative frequency of the soil organisms groups in the summer sampling was similar to that in the winter, when Collembola was the group more frequently found (Figure 2). However, in NT and ICLAcarina was dominant and in the other LUS (PA, EP and NF) Formicidae was predominant. In EP Isopoda also was found frequently (Figure 2).

The groups found in higher frequency (Collembola Acarina, Coleoptera and Formicidae), independent of LUS, are consistent with the results found by Baretta et al. (2006) in the West region of Santa Catarina, where a dominance of Collembola and Acarina were found, especially in no-tillage systems. The authors attributed this result to good soil management and organic fertilization with swine manure.

Samples taken in the late winter season (August 2011) show the following results: in NF 17 groups, in NT 16 groups, in ICL 15 groups and in PA and EP 13 taxonomic groups (Table 2). The soil fauna's total abundance was significantly higher in the LUS with more anthropic impact (NT, ICL and PA), comparing to the EP and NF sites with lower human impact (Table 2).

In the summer season, 17 groups of organisms in NF, 15 in EP, 14 in ICL and NT and 13 groups on PA (Table 2) were found. Total abundance of soil fauna in the summer was significantly higher only in NT (Table 2).

However, the Shannon index (H') in both seasons, followed a gradient of anthropic impact
$(\mathrm{NF}>\mathrm{EP}>\mathrm{PA}>\mathrm{ICL}>\mathrm{NT})$, expressing higher diversity and uniformity of taxonomic groups in the less impacted LUS. The Pielou index presented a similar result. This index shows which LUS have better distribution of abundance of the groups (values near 1), and there was only an inversion in the LUS, ICL and NT. For both indexes winter season were higher compared to those found in the summer.

Significant differences in total abundance the LUS were found between the two sampling seasons and were observed only in NF and NT where higher abundance was found in the summer (Table 2). Moço et al. (2005) and Santos et al. (2008) observed higher soil fauna abundance in the winter compared with the summer season, attributing this to the fact that during the summer of that year there was a drought when there were months without rain.

The presence or absence of a particular group of soil/litter fauna in the LUS studied was quite variable and not consistent between winter and summer. Some authors consider that native or natural forest, in general, have higher values of abundance and richness of soil fauna than the soil and litter layer of Eucalyptus plantation and pasture, although in the present study they were similar in both sampling seasons. In general, the more diverse the vegetation, the greater the heterogeneity of the litter, which results in a higher diversity of fauna communities (CORREIA; ANDRADE, 2008).

In NT and ICL, similar richness of soil fauna groups was found by Santos et al. (2008) when they evaluated soil macrofauna associated with different soil cover: in NT, in a Typic Haplustox and in the Cerrado biome, using Principal Component Analysis (PCA).

The PCA analysis demonstrated through the relationship between the principal component 1 (PC 1) and principal component 2 (PC 2), a separation of the five LUS in both winter (Figure 3) and summer (Figure 4) 
seasons. The variability in the data explained was $32.7 \%$ for PC 1 and $20.4 \%$ for PC 2 in the winter (Figure 3) and in the summer season $32.9 \%$ for PC 1 and $20.9 \%$ for PC 2 (Figure 4 ). The third principal component (PC 3) explained very little and was disregarded.

Still, in both winter and summer soil fauna was influenced by seasonality, as changes occurred in the distribution of taxonomic groups, and the greater or lesser degree of association of these groups in each LUS can be seen in Figure 3 (winter) and Figure 4 (summer).

In winter, NF and PA were correlated with most groups of soil fauna found, compared to NT, ICL and EP (Figure 3), and especially to the groups Formicidae, Araneae, Hymenoptera, Homoptera, Thysanoptera, Gryllobrattodea, Blattodea, Orthoptera and Others (unidentified organisms). In these LUS it was mainly due to higher $\mathrm{pH}$ values (SMP method and water) and clay contents. The EP sites were associated with the groups Isopoda, Isoptera and Dermaptera, especially due to higher contents of $\mathrm{K}$ and $\mathrm{P}$. These higher values of $\mathrm{K}$ and $\mathrm{P}$ are explained, in part, because this site had received chemical fertilization. On the other hand, the sites ICL and NT were associated with the groups Collembola, Acarina, Diplopoda, Chilopoda and Hemiptera, but these groups did not have any correlation to chemical attributes.

Figure 3 - Relationship between the principal component 1 (PC 1) and the principal component 2 (PC 2), considering the land use system, the soil/litter fauna groups $(\rightarrow)$ and the selected explicative environmental attributes $(\rightarrow)$ in the winter season in the western region of Santa Catarina, Brazil. (NT: no-tillage, ICL: integrated crop-livestock, PA: pasture, EP: Eucalyptus plantation and NF: native forest, K: potassium, P: phosphorous, SMP: SMP: potencial acidity SMP, $\mathrm{pHw}$ : water $\mathrm{pH}$ )

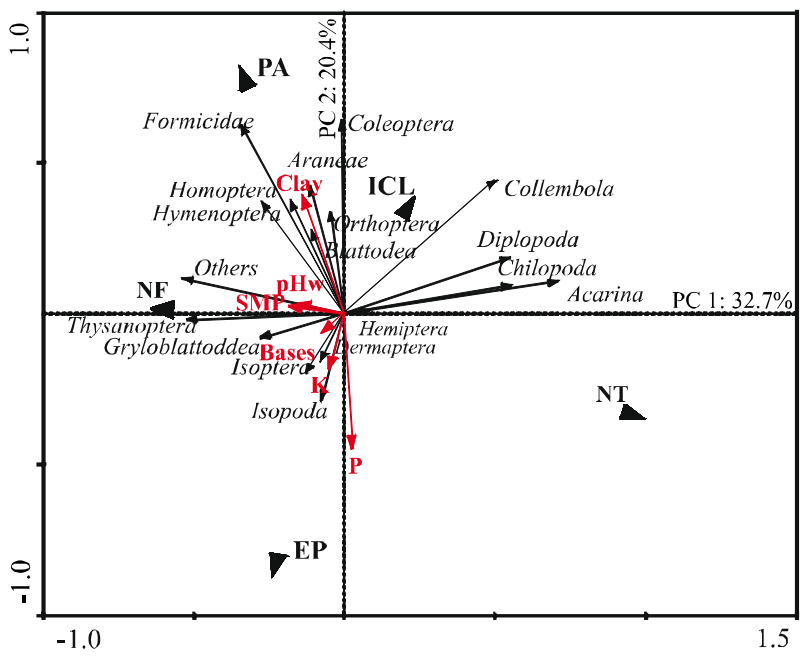

Figure 4 - Relationship between the principal component 1 (PC 1) and the principal component 2 (PC2), taking into account the land use systems, the soil/litter fauna groups $(\rightarrow)$ and the selected explicative environmental attributes $(\rightarrow)$ in the winter season in the western region of Santa Catarina, Brazil. (NT: no-tillage, ICL: integrated crop-livestock, PA: pasture, EP: Eucalyptus plantation and NF: native forest, $\mathrm{P}$ : phosphorous, $\mathrm{Ca}$ : calcium, $\mathrm{Al}$ : aluminum, $\mathrm{H}+\mathrm{Al}$ : potential acidity, $\mathrm{OM}$ : organic matter, $\mathrm{pHw}$ : water $\mathrm{pH}$ )

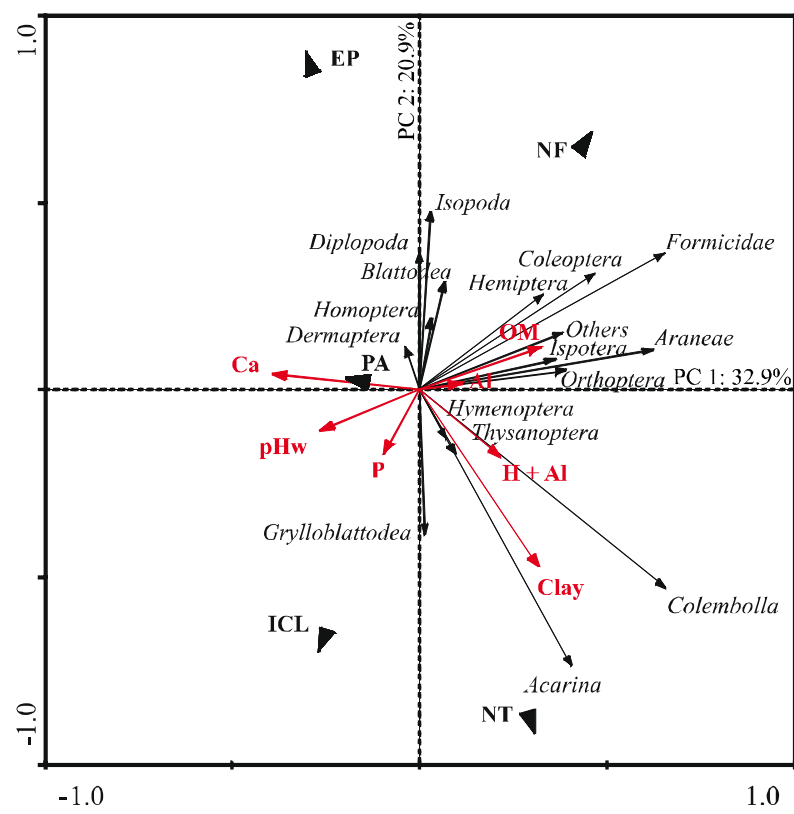

Fauna abundance distribution in the summer differed from those found in the winter, i.e. NF and EP were associated with a higher number of taxonomic groups and with some environmental attributes ( $\mathrm{Ca}, \mathrm{Al}$ and $\mathrm{OM}$ ). Collembola and Acarina were strongly associated with NT, especially due to higher soil clay content, agreeing with results obtained by Baretta et al. (2006) for the same region in this study.

Springtails (Collembola) were the most abundant group in this study by a significant margin, independent of the LUS. This group is widely distributed and abundant in the soil and litter layer and its abundance is influenced by the presence of organic matter, and they are considered opportunistic as they grow rapidly under suitable conditions. The main effect of springtail activity is the promotion of the decomposition process in soil. This happens directly due to the amount of decaying vegetation and fungal hyphae, and indirectly due to the stimulation of microorganisms involved in decomposition (ANTONIOLLI et al., 2006).

Nevertheless, we suggest that further studies involve separation/identification to species level, family or even morphotyping, because some species of soil/litter 
fauna, such as springtails, are considered indicators of soil quality. The presence or absence of specific species may be related to changes in $\mathrm{pH}$, availability of particular ions and water, the presence of components of pesticides or heavy metals from contaminated soils (BARETTA et al., 2008b). The presence and abundance of endemic species may also be indicative of environmental impacts (BELLINI; ZEPPELINI, 2009).

NF showed higher richness and diversity of groups compared to sites with other LUS, and Formicidae, Coleoptera, Isoptera, Araneae and Isopoda (macrofauna), were more abundant and associated with a higher content of organic matter $(\mathrm{OM})$, which is the food for these faunal groups or their prey (ALVES; BARETTA; CARDOSO, 2006). OM interacts closely with many biological components (BARETTA et al., 2006), including other trophic levels such as populations of springtails (mesofauna) (BARETTA et al., 2008b).

Many families of Coleoptera are highly specialized in the ecological niche they occupy. One of their functions is, for example, the decomposition of plants and animals (KIM, 1993). In forest ecosystems, Coleoptera are involved in nutrient cycling and the seed dispersal process can be used to assess the effects of forest disturbance. Beetles are mostly detritivorous, promoting both the removal and introduction of organic matter in nutrient cycling, increasing soil aeration and prolonging the soil's productive capacity (MILHOMEM et al.,2003), earning them special attention and acknowledgement for their distinct characteristics via morphotyping.

The Formicidae community structure has been reported as being crucial in environmental impact studies because of this group's function in the redistribution of particles, nutrients and organic matter, thus improving water infiltration into the soil, and allowing for better porosity and aeration (NAKAMURA et al., 2011). In this study they were shown to be more prevalent in LUS with less anthropic impact (NF, EP and PA).

However, the ACP showed that in addition to the spatial separation of LUS in winter and in summer seasons, there were differences in the distribution of faunal groups (Figures 3 and 4), where some groups were more sensitive to changes in land use than others. Thus, when identified by group, soil/litter fauna have the potential to be used as an indicator of biological sustainability of a system and as bioindicators of soil quality (BARETTA et al., 2011). We suggest future studies at the family or species levels for some of these groups or even separation by morphotyping (due to a lack of taxonomists in Brazil), to better understand the relationships of fauna with soil processes.
It is known that higher or lower sensitivity of each soil/litter fauna group in different LUS is particularly affected by climatic conditions (seasons), the type of soil management, the history of the sites, the chemical condition of the soil, and other factors such as higher quantity and quality of plant residue (litter layer). All of these together provide a more or less favorable environment for the survival of soil/litter organisms.

\section{CONCLUSIONS}

The presence of groups of soil/litter fauna was influenced by the type of soil management used. Environmental characteristics are determinant in soil/ litter organism abundance and diversity:

1. The abundance of soil/litter fauna and environmental attributes are potentially useful as indicators of soil quality, as they are sensitive to interference in the environment, facilitating decision making for more sustainable land management practices;

2. The less impacted LUS (NF, EP and PA) provide better soil conditions for the development of higher diversity in soil/litter fauna groups, compared to other land use systems which showed varying degrees of human intervention, regardless of sampling season (winter or summer);

3. Principal component analysis (PCA) is an important tool in the study of biological indicators of sustainability because it allows use of soil attributes (chemical and physical) as explanatory environmental variables, aiding in the interpretation of ecological data.

\section{ACKNOWLEDGMENT}

The authors acknowledge the financial support of this project by FAPESC Project no. 6.309/2011-6 and CNPq Project no. 563251/2010-7 and thank the farmers for authorizing sampling on their properties. Special thanks are also given to Gilberto Francosi and the graduate and undergraduate students of UDESC/CEO for technical assistance, and Susie James (Fairfield, Iowa, EUA) and the anonymous referees for their critical and helpful comments.

\section{REFERENCES}

ALVES, V.M; BARETTA. D; CARDOSO, E.B.N., Fauna edáfica em diferentes sistemas de cultivo no estado de São Paulo. Revista de Ciências Agroveterinárias, v. 5, n. 1, p. 3343, 2006.

ANTONIOLLI, Z. I. et al. Método alternativo para estudar a fauna do solo. Ciência Florestal, v. 16, n. 4, p. 407-417, 2006. 
ARAÚJO, A. S. F.; MONTEIRO, R. T. R. Indicadores biológicos de qualidade do solo. Bioscience Journal, v. 23, p. 66-75, 2007.

BARETTA, D.; BARETTA, C. R. D. M.; CARDOSO, E. J. B. N. Análise multivariada de atributos microbiológicos e químicos do solo em florestas com Araucaria angustifolia. Revista Brasileira de Ciência do Solo, v. 32, p. 2683-2691, 2008a.

BARETTA, D. et al. Colêmbolos (Hexapoda: collembola) como bioindicadores de qualidade do solo em áreas com Araucaria angustifolia. Revista Brasileira de Ciência do Solo, v. 32, p. 26932699,2008 b.

BARETTA, D. et al. Análise multivariada da fauna edáfica em diferentes sistemas de preparo e cultivo do solo. Pesquisa Agropecuária Brasileira, v. 41, n. 11, p. 1675-1679, 2006.

BARETTA, D. et al. Fauna edáfica e qualidade do solo. In: KLAUBERG FILHO, O.; MAFRA, A.L. (Org.). In: Tópicos em Ciência do Solo. Viçosa: Sociedade Brasileira de Ciência do Solo, 2011, v. 7, p. 119-170.

BARTZ, M. L. C.; PASINI, A.; BROWN, G. G. Earthworms as soil quality indicators in Brazilian no-tillage systems. Applied Soil Ecology. v. 69, 39-48, 2013.

BARTZ, M.L.C. et al. Earthworm richness in land-use systems in Santa Catarina, Brazil. Applied Soil Ecology, 2014. No prelo: http://dx.doi.org/10.1016/j.apsoil. 2014.03.003.

Benito, N. P.; GuimarÃes, M. DE F.; PASIni, A. Caracterização de sistemas de manejo em Latossolo Vermelho utilizando parâmetros biológicos, físicos e químicos. Semina: Ciências Agrárias, v. 29, p. 473-484, 2008

BELLINI, B. C.; ZEPPELINI, D. Registros da fauna de Collembola (Arthropoda, Hexapoda) no Estado da Paraíba, Brasil. Revista Brasileira de Entomologia, v. 53, n. 3, p. 386390, 2009.

BONEA, J. et al. Soil quality assessment under emerging regulatory requirements. Environment International, v. 36, n. 6, p. 609-622, 2010.

BROWN, G. G. et al. No-tillage greatly increases earthworm populations in Paraná state, Brazil. Pedobiologia, v. 47, p. 764$771,2003$.

CORREIA, M. E. F; ANDRADE, A. G. Formação de serapilheira e ciclagem de nutrientes. In: SANTOS, G. A.; SILVA, L. S.; CANELlAS, L. P.; CAMARGO, F. A. O. (Ed.) Fundamentos da matéria orgânica do solo: ecossistemas tropicais \& subtropicais. 2. ed. rev. e atual. - Porto Alegre: Metropole, 2008. cap. 10, p. 137-158.

EMPRESA BRASILEIRA DE PESQUISA AGROPECUÁRIA. Sistema brasileiro de classificação de solos, $2^{\mathrm{a}}$ Ed. Embrapa Solos, Rio de Janeiro, 2009, 306 p.
FONTE, S. J. et al. Interactive effects of plants and earthworms on the physical stabilization of soil organic matter in aggregates. Plant Soil, v. 359, p. 205-214, 2012.

HUERTA, E.; WAL, H. Soil macroinvertebrates abundance and diversity in home gardens in Tabasco, Mexico, vary with soil texture, organic matter and vegetation cover. European Journal of Soil Biology. v. 50, p. 68-75, 2012.

KIM, K. C. Biodiversity, conservation and inventory: Why insects matter. Biodiversity and Conservation, v. 2, p. 191214, 1993.

KNOEPP, J. D. et al. Biological indices of soil quality: an ecosystem case study of their use. Forest Ecology and Management, v. 138, p. 357-368, 2000.

LIMA, A. C. R. et al. A functional evaluation of three indicator sets for assessing soil quality. Applied Soil Ecology, v. 64, p. 194-200, 2013.

MILHOMEM, M. S.; MELLO, F. Z. V. de; DINIZ, I. R. Técnicas de coleta de besouros copronecrófagos no Cerrado. Pesquisa Agropecuária Brasileira, v. 38, n. 11, p. 1249-1256, 2003.

MOÇO, M. K. da S. et al. Caracterização da fauna edáfica em diferentes coberturas vegetais na região norte fluminense. Revista Brasileira de Ciência do Solo, v. 29, n. 4, pp. 555-564, 2005.

NAKAMURA, A. et al. The use of ants and other soil and litter arthropods as bio-indicators of the impacts of rainforest clearing and subsequent land use. Journal of Insect Conservation, v. 11, p. 177-186, 2011.

ODUM, E. P. Ecologia. Rio de Janeiro, 1983, 434 p.

SANTOS, G. G. et al. Macrofauna edáfica associada a plantas de cobertura em plantio direto em um Latossolo Vermelho do Cerrado. Pesquisa Agropecuária Brasileira, v. 43, n. 1, p. 115122, 2008.

STATSOFT INC. Statistica (data analysis software system), version 6. Tulsa, OK, USA, 2001.

SOIL SURVEY STAFF. Keys to soil taxonomy. 11.ed. Washington: United States Department of Agriculture. Natural Resources Conservation Service, 2010. 338p.

TEDESCO, M. J. et al. Análises de solo, plantas e outros materiais. Porto Alegre, Universidade Federal do Rio Grande do Sul, 1995, 174 p, (Boletim Técnico 5).

TER BRAAK, C. J. F.; SMILAUER, P. CANOCO reference manual and user's guide to Canoco for Windows: software for canonical community ordination (version 4). New York: Microcomputer Power, 1998.

VASCONCELLOS, R. L. et al. Soil macrofauna as an indicator of soil quality in an undisturbed riparian forest and recovering sites of different ages. European Journal of Soil Biology, v. 58, p. $105-112,2013$. 